\title{
Brazing of micrograin-filled quartz fiber reinforced silica composites and Invar using Ag-21Cu-4.5Ti alloy
}

\author{
ZHAO Lei*, FENG JiCai, TIAN XiaoYu, ZHANG LiXia \& HE Peng \\ State Key Laboratory of Advanced Welding Production Technology, Harbin Institute of Technology, Harbin 150001, China
}

Received December 26, 2010; accepted April 29, 2011

Brazing of quartz fiber reinforced silica composites (QFSC) to Invar alloy was carried out in a vacuum at $1173 \mathrm{~K}$ for $10 \mathrm{~min}$ using $\mathrm{Ag}-21 \mathrm{Cu}-4.5 \mathrm{Ti}$ metal filler. Experiments indicated that composites prefilled with $\mathrm{CaCO}_{3}$ micrograins had good wettability. The $\mathrm{CaCO}_{3}$ decomposed to $\mathrm{CaO}$ during brazing. After brazing, a joint of structure $\mathrm{QFSC} / 3 \mathrm{CaO} \cdot 2 \mathrm{SiO}_{2}+\mathrm{Ti}_{3} \mathrm{O}_{5}+\mathrm{Fe} 2 \mathrm{Ti}+\mathrm{NiTi}+\mathrm{Ag}(\mathrm{s}, \mathrm{s})+$ $\mathrm{Cu}(\mathrm{s}, \mathrm{s}) /$ Invar was established. The shear strength of the brazed joint reached $11.6 \mathrm{MPa}$ at room temperature, which is about five times the shear strength of that obtained without surface filling.

composites, wettability, filler reinforcement, brazing, microstructure, strength

Citation: Zhao L, Feng J C, Tian X Y, et al. Brazing of micrograin-filled quartz fiber reinforced silica composites and Invar using Ag-21Cu-4.5Ti alloy. Chinese Sci Bull, 2011, 56: 2869-2873, doi: 10.1007/s11434-011-4569-x

In the field of advanced composites, fiber braided composites are increasingly receiving attention because they are lightweight, and have excellent mechanical strength and high temperature resistance [1-4]. Quartz fiber reinforced silica composites (QFSCs) also have special electrical properties. Because they have poor machining properties, one focus of research into applications of these composites is on joining them with dissimilar materials.

Recently, research into joining of fiber braided composites has focused mainly on brazing [5-8]. It has been suggested that fiber braided composites have low interlaminar contact strengths because their loose texture results in poor dynamic properties [9,10]; this could make it difficult to form perfect joints at the interfaces. Several techniques have been considered for reinforcement of composites, such as resin transfer molding and vacuum assisted resin transfer molding for different textile performs (2D or 3D textile architectures) [11]. Filler reinforcement using micrograins is an effective modification for reinforcing incompact structures $[12,13]$. We may infer that good joints could be

*Corresponding author (email: zlei3320@yahoo.com.cn) achieved by reinforcing fiber braided composites with fillers. The aim of our investigation was to study the brazing of Invar alloy to QFSC through experiments examining the effects of micrograin fillers on the composite surface, using $\mathrm{Ag}-21 \mathrm{Cu}-4.5 \mathrm{Ti}$ as the braze filler metal. The microstructure and joining mechanism were also investigated.

\section{Experimental}

The QFSC was synthesized by immersion sintering of quartz fibers and silica sol. The composite had different strengths in different directions (the shear strength in the vertical direction reached $160 \mathrm{MPa}$, but in the parallel direction was only $10.6 \mathrm{MPa}$ ). In the present study, the surface parallel to the orientation of the fibers was used for brazing. Commercial Invar alloy (see Table 1 for the chemical composition) was used as the substrate, and the filler metal used in the vacuum brazing was commercial $\mathrm{Ag}-21 \mathrm{Cu}-4.5 \mathrm{Ti}$ foil.

The QFSC samples (thickness $5 \mathrm{~mm}$ ), Invar alloy (thickness $5 \mathrm{~mm}$ ), and filler metal (thickness $50 \mu \mathrm{m}$ ) were cut into slices of dimensions $5 \mathrm{~mm} \times 5 \mathrm{~mm}$, and cleaned ultrasonically in 
Table 1 Chemical composition of Invar alloy (wt.\%)

\begin{tabular}{ccccccc}
\hline $\mathrm{Fe}$ & $\mathrm{Ni}$ & $\mathrm{Mn}$ & $\mathrm{Si}$ & $\mathrm{S}$ & $\mathrm{C}$ & $\mathrm{P}$ \\
\hline Remaining & $35.0-37.0$ & $0.2-0.6$ & 0.2 & 0.02 & 0.02 & 0.05
\end{tabular}

acetone for $15 \mathrm{~min}$.

After cleaning and air-drying, the QFSC was dipped into $\mathrm{Ca}(\mathrm{OH})_{2}$ solution, followed by $\mathrm{CO}_{2}$ gas insufflation (gas velocity $0.008 \mathrm{~m} \mathrm{~s}^{-1}$ ) for $15 \mathrm{~min}$. The QFSC surface was then wiped using a pledget dipped in acetone. The micrograin-filled QFSC was prepared by this step. The Invar substrates were polished using metallographic abrasive papers.

The assemblages of QFSC/Ag-21Cu-4.5Ti/Invar were brazed in a vacuum at $1173 \mathrm{~K}$ for $10 \mathrm{~min}$, with a normal load of $0.02 \mathrm{MPa}$, using micrograin-filled QFSC. The heating and cooling rates were $10 \mathrm{~K} \mathrm{~min}^{-1}$. To compare the strengths of the joints, the original QFSC was also brazed to Invar using Ag-21Cu-4.5Ti foil under the same conditions.

The shear strengths of the joints were tested using a materials testing machine (Instron-5569, Instron, Norwood, MA, USA) with a loading rate of $1 \mathrm{~mm} \mathrm{~min}^{-1}$. The crosssectional microstructures of the brazed joints were examined using a scanning electron microscope (SEM S-4700, Hitachi, Tokyo, Japan) equipped with an energy-dispersive spectrometer (EDS) and an electron probe X-ray microana- lyzer (EPMA). The reaction products were identified by Xray diffraction (XRD; JDX-3530M, JEOL, Tokyo, Japan).

\section{Results and discussion}

\subsection{Microstructure and joint strength}

As shown in Figure 1(a), the joint obtained with QFSC/ Invar brazed directly using a $\mathrm{AgCuTi}$ alloy has an imperfect junction, and the interface near the QFSC has been fragmented into small pieces. The joint obtained with Invar and QFSC predeposited with micrograins had good wetting properties and a strong connection (Figure 1(b)). The results of the EDS line scan across the joining interface are shown in Figure 1(c). It can be seen from Figure 1(c) that Fe and $\mathrm{Ni}$ diffuse into the brazing seam. The distribution of $\mathrm{Ni}$ is 15-20 at.\% and that of $\mathrm{Fe}$ is greater than 40 at.\%. However, the distribution is not uniform in the brazing zone. In contrast, the $\mathrm{Cu}$ and $\mathrm{Ag}$ contents of the joint are both in the range $60-80$ at.\%. Ti is found mainly in two parts: $15-20$ at.\% aggregated with $\mathrm{Fe}$ and $\mathrm{Ni}$ at the center of the junction, and almost 45 at.\% diffused into the interface of the composite. The total $\mathrm{Ca}$ content is so low that it can be dismissed as simple deposition.

To examine the joint properly, it is necessary to look at the microstructures of the Invar/AgCuTi and AgCuTi/QFSC
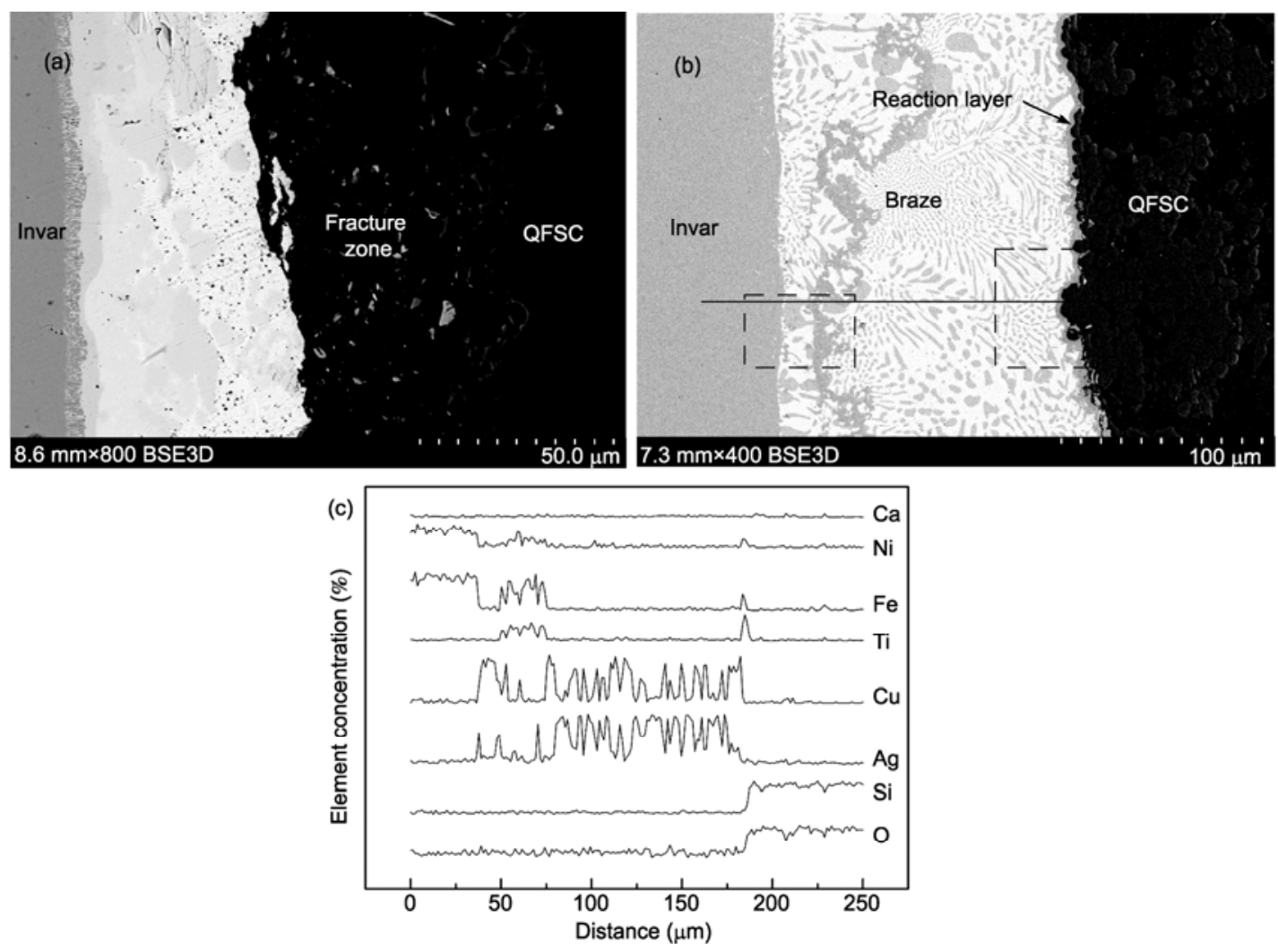

Figure 1 Microstructure of (a) QFSC/Invar, (b) micrograin-filled QFSC/Invar and (c) EDS line scan results of junction in (b), brazed with AgCuTi alloy at $1173 \mathrm{~K}$ for $10 \mathrm{~min}$. 
interfaces (see Figure 2). The results of spot EDS analyses across the joining interfaces are shown in Table 2, with each position referred to in Figure 2. The gray blocks near the Invar are $\mathrm{Cu}$-rich phases containing little $\mathrm{Fe}$ and $\mathrm{Ni}$, so they are $\mathrm{Cu}$-based solid solutions $(\mathrm{Cu}(\mathrm{s}, \mathrm{s}))$ in terms of the $\mathrm{Cu}-\mathrm{Fe}$ phase diagram. At the joint center, some $\mathrm{Ti}$ and a little $\mathrm{Ni}$ are found in the layer of Fe-rich phase (black strip in Figure 2). Some intermetallic compounds may be formed between $\mathrm{Ti}$ and $\mathrm{Fe}$, and $\mathrm{Ti}$ and $\mathrm{Ni}$. The elements in the white matrix of the joint seam are $\mathrm{Ag}, \mathrm{Cu}$, and $\mathrm{O}$; the amount of $\mathrm{Ag}$ is higher than the amounts of $\mathrm{Cu}$ and $\mathrm{O}$, from which it can be inferred that a Ag-based solid solution is formed in this white region. On the composites side, a gray layer of composition 19.60 at.\% $\mathrm{O} / 38.05$ at.\% Ti/18.19 at.\% Fe/15.61 at.\% $\mathrm{Ni}$ is found adjacent to the QFSC border, which may also be composed of intermetallic compounds and oxides. It is clear that reaction occurs between the quartz fiber surface and the filler metal.

To identify the reaction phases of the joint further, the specimens brazed at $1173 \mathrm{~K}$ for $10 \mathrm{~min}$ were ground to expose the reaction layer at the interface. XRD analysis was then performed on the interface reaction layer; the results are shown in Figure 3. From previously reported results [14, 15], it can be inferred from Figure 3 that the reaction products in the gray layer are mainly $\mathrm{Ti}_{3} \mathrm{O}_{5}, \mathrm{Fe}_{2} \mathrm{Ti}$, and NiTi. Because the gray layer is only about $3 \mu \mathrm{m}$ thick and near the QFSC quartz fibers and the filler metal, some of the phases in the XRD pattern can easily be identified as $\mathrm{SiO}_{2}$, $\operatorname{Ag}(\mathrm{s}, \mathrm{s})$, and $\mathrm{Cu}(\mathrm{s}, \mathrm{s})$.

Combining the results discussed above, the reaction phases can be identified as follows: the gray blocks near the Invar are a $\mathrm{Cu}$-based solid solution; the black strips at the center of the junction are composed of $\mathrm{Fe}_{2} \mathrm{Ti}$ and $\mathrm{NiTi}$; the white phase is a Ag-based solid solution; and the reaction layer adjacent to the QFSC is composed of $\mathrm{Fe}_{2} \mathrm{Ti}, \mathrm{Ti}_{3} \mathrm{O}_{5}$, and NiTi.

In the brazing process, quartz fibers reacted with $\mathrm{CaO}$, formed by decomposition of $\mathrm{CaCO}_{3}$ predeposited at the surface of QFSC (eq. (1)) at high temperature, to form silicate (eqs. (2)-(5)). As reported in [15], silicate is a type of ionic compound. Silicate formation would generate free $\mathrm{O}$ ions. The d-orbitals of $\mathrm{Ti}$ atoms have vacant electron sites, which could easily form pairs of electrons or covalent bonds with $\mathrm{O}$ ions. As a consequence, the reaction between $\mathrm{CaO}$ and silica provided an important support for interaction of the braze alloy.

The joint shearing test showed that the joint shear strength can reach $11 \mathrm{MPa}$ at room temperature, which is equal to the composite strength paralleled with fibers. For comparison, the shear strength of a brazed joint without micrograin filling was tested; the results are shown in Table 3 . It is evident that surface filling plays an active role in joining, and the joint strength is improved by more than five times.

\subsection{Thermodynamic analyses}

In the joining process, three main reactions occur at different periods. The relevant thermodynamic processes are discussed in the following.

As a result of reaction (1) in $\mathrm{Ca}(\mathrm{OH})_{2}$ solution at room

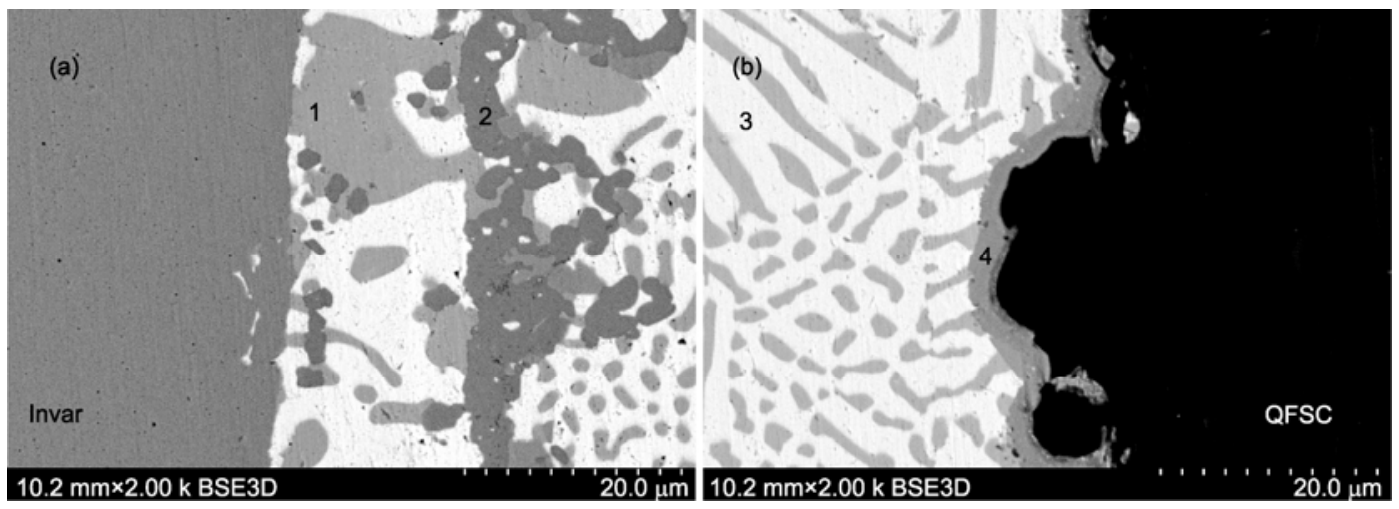

Figure 2 SEM micrographs of the interfaces of (a) Invar/AgCuTi, and (b) AgCuTi/QFSC, marked on the joint in Figure 1(b).

Table 2 Chemical compositions of each region in different zones of Invar/QFSC joint brazed using AgCuTi filler metal at $1173 \mathrm{~K}$ for 10 min (at.\%)

\begin{tabular}{lccccccccc}
\hline \multicolumn{1}{c}{ Sites } & $\mathrm{O}$ & $\mathrm{Si}$ & $\mathrm{Ag}$ & $\mathrm{Ca}$ & $\mathrm{Ti}$ & $\mathrm{Fe}$ & $\mathrm{Ni}$ & $\mathrm{Cu}$ & $\mathrm{Possible} \mathrm{phases}$ \\
\hline 1 (gray block) & 04.02 & 01.52 & 03.28 & 01.05 & 00.80 & 04.06 & 03.21 & 82.06 & $\mathrm{Cu}(\mathrm{s}, \mathrm{s})$ \\
2 (black strip) & 08.07 & 01.02 & 09.76 & 00.12 & 23.78 & 43.56 & 11.02 & 02.67 & $\mathrm{Fe}_{2} \mathrm{Ti}, \mathrm{NiTi}$ \\
3 (white region) & 17.16 & 00.00 & 59.95 & 00.00 & 00.99 & 05.81 & 05.88 & 10.21 & $\mathrm{Ag}(\mathrm{s}, \mathrm{s})$ \\
4 (gray layer) & 19.60 & 05.24 & 00.83 & 00.42 & 38.05 & 18.19 & 15.61 & 02.06 & $\mathrm{Ti}_{3} \mathrm{O}_{5}, \mathrm{NiTi}_{2} \mathrm{Fe}_{2} \mathrm{Ti}$ \\
\hline
\end{tabular}




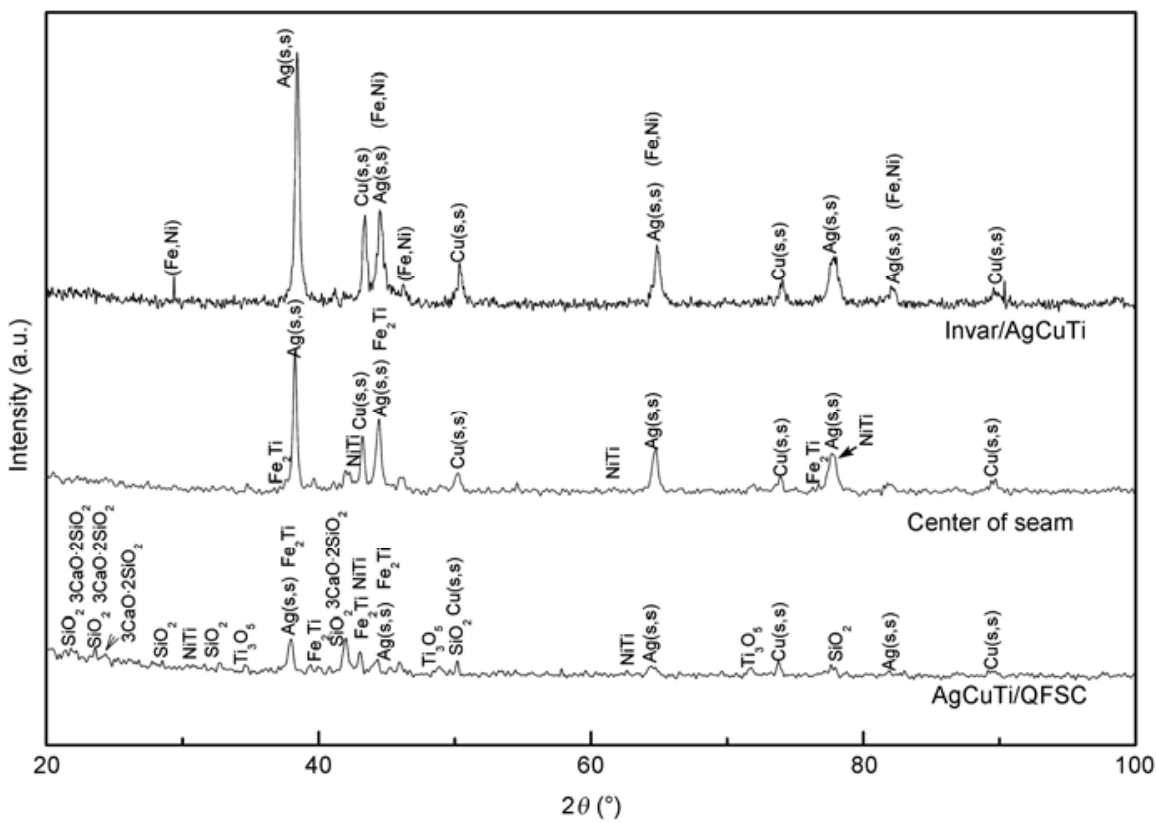

Figure 3 XRD result for micrograin-filled QFSC/Invar joint brazed at $1173 \mathrm{~K}$ for $10 \mathrm{~min}$ using AgCuTi alloy filler.

Table 3 Shear strengths of QFSC/AgCuTi/Invar and micrograin-filled QFSC/AgCuTi/Invar brazed at $1173 \mathrm{~K}$ for $10 \mathrm{~min}$

\begin{tabular}{lcccl}
\hline \multicolumn{1}{c}{ Type of sample assembled } & Brazing technique & Shear strength of joint (MPa) & \multicolumn{1}{c}{ Remarks } \\
\hline QFSC/Ag-21Cu-4.5Ti/Invar & $1173 \mathrm{~K}$ & $10 \mathrm{~min}$ & $0,1.5,1.8$ & $\begin{array}{l}\text { Not joined and cracking at QFSC side } \\
\text { Cracking at QFSC beside brazing seam for 0.5 mm, } \\
\text { Micro-grains filled QFSC/ }\end{array}$ \\
\begin{tabular}{l} 
Ag-21Cu-4.5Ti/Invar \\
\hline
\end{tabular}
\end{tabular}

temperature, a large number of white grains are deposited at the surface of the quartz fibers:

$$
\mathrm{Ca}^{2+}(\mathrm{aq})+2 \mathrm{OH}^{-}(\mathrm{aq})+\mathrm{CO}_{2}(\mathrm{aq}) \rightarrow \mathrm{CaCO}_{3}(\mathrm{~s})+\mathrm{H}_{2} \mathrm{O}(\mathrm{l})
$$

The Gibbs free energy, calculated using the software package HSC Chemistry 5.0 (Outotec Oyj, Finland), is: $\Delta_{\mathrm{r}} G_{(1)}=-72.623 \mathrm{~kJ} \mathrm{~mol}^{-1}$.

In the heating process, the solid $\mathrm{CaCO}_{3}$ deposited can be decomposed above $1118 \mathrm{~K}$ [16]:

$$
\mathrm{CaCO}_{3}(\mathrm{~s}) \rightarrow \mathrm{CaO}(\mathrm{s})+\mathrm{CO}_{2}(\mathrm{~g})
$$

After this step, micrograins of $\mathrm{CaO}$ are deposited on the surface of the quartz fibers in QFSC. $\mathrm{CaO}$ grains probably then react with the quartz fibers as shown in eqs. (3), (4), or (5).

$$
\begin{gathered}
2 \mathrm{CaO}(\mathrm{s})+\mathrm{SiO}_{2}(\mathrm{~s}) \rightarrow 2 \mathrm{CaO} \cdot \mathrm{SiO}_{2}(\mathrm{~s}) \\
3 \mathrm{CaO}(\mathrm{s})+\mathrm{SiO}_{2}(\mathrm{~s}) \rightarrow 3 \mathrm{CaO} \cdot \mathrm{SiO}_{2}(\mathrm{~s}) \\
3 \mathrm{CaO}(\mathrm{s})+2 \mathrm{SiO}_{2}(\mathrm{~s}) \rightarrow 3 \mathrm{CaO} \cdot 2 \mathrm{SiO}_{2}(\mathrm{~s})
\end{gathered}
$$

In addition, reactions could occur between $\mathrm{Ti}$ and $\mathrm{Fe}$, or $\mathrm{Ti}$ and $\mathrm{Ni}$. The corresponding reaction equations are

$$
2 \mathrm{Fe}(\mathrm{s})+\mathrm{Ti}(\mathrm{s}) \rightarrow \mathrm{Fe}_{2} \mathrm{Ti}(\mathrm{s})
$$

$$
\mathrm{Ni}(\mathrm{s})+\mathrm{Ti}(\mathrm{s}) \rightarrow \mathrm{NiTi}(\mathrm{s})
$$

In the brazing process, the $\mathrm{Ti}$ in the AgCuTi active foil could react with quartz fibers as in eq. (8).

$$
3 \mathrm{Ti}(\mathrm{s})+2.5 \mathrm{SiO}_{2}(\mathrm{~s}) \rightarrow \mathrm{Ti}_{3} \mathrm{O}_{5}(\mathrm{~s})+2.5 \mathrm{Si}(\mathrm{s})
$$

The calculated Gibbs free energy values for eqs. (3) to (7) are shown in Figure 4. And the Gibbs free energy for eq. (8) is in the range of $-1959.802 \mathrm{~kJ} \mathrm{~mol}^{-1}$ to $-1934.537 \mathrm{~kJ} \mathrm{~mol}^{-1}$

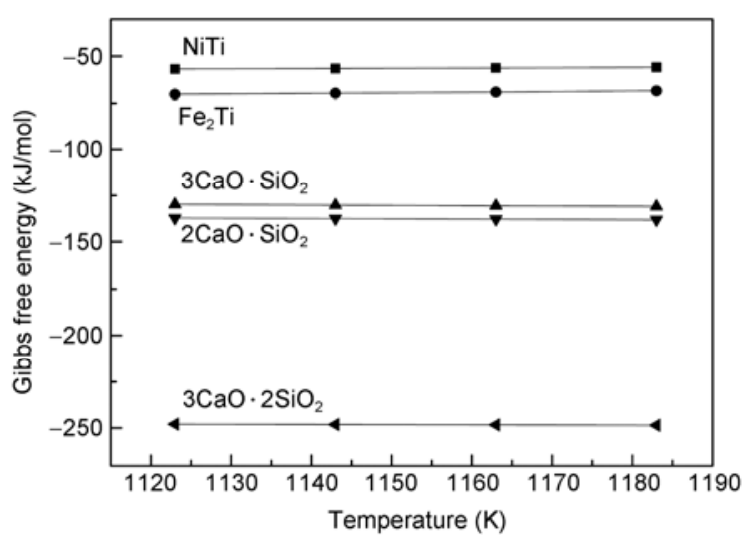

Figure 4 Free energies of formation of possible reaction products formed during brazing. 
from 1123 to $1183 \mathrm{~K}$. It has been confirmed that all these reaction products can be produced in the joining process; the thermodynamic data suggest that $3 \mathrm{CaO} \cdot 2 \mathrm{SiO}_{2}$ is the most likely product of reaction between $\mathrm{CaO}$ and $\mathrm{SiO}_{2}$.

In summary, it can be that the reaction products at the interface are $3 \mathrm{CaO} \cdot 2 \mathrm{SiO}_{2}, \mathrm{Ti}_{3} \mathrm{O}_{5}, \mathrm{Fe}_{2} \mathrm{Ti}$, and NiTi.

\subsection{Process model}

Based on the results discussed above, the vacuum brazing of Invar and a QFSC surface filled with micrograins is described in Figure 5. At room temperature, QFSC surface deposited by $\mathrm{CaCO}_{3}$ micrograins, base material, and $\mathrm{AgCuTi}$ filler metal are assembled. In the heating period, $\mathrm{CaCO}_{3}$ grains are gradually transformed into $\mathrm{CaO}$ micrograins above $1118 \mathrm{~K}$; the micrograins can react with quartz fibers to form a solid solution. The filler alloy reacts with the quartz fibers and Invar simultaneously in the brazing period to form a compact joint. After cooling, a joint interface consisting of $3 \mathrm{CaO} \cdot 2 \mathrm{SiO}_{2}, \mathrm{Ti}_{3} \mathrm{O}_{5}, \mathrm{Fe}_{2} \mathrm{Ti}$, NiTi, $\mathrm{Ag}(\mathrm{s}, \mathrm{s})$, and $\mathrm{Cu}(\mathrm{s}, \mathrm{s})$ is formed. The joint structure can be described as: QFSC/ $3 \mathrm{CaO} \cdot 2 \mathrm{SiO}_{2}+\mathrm{Ti}_{3} \mathrm{O}_{5}+\mathrm{Fe}_{2} \mathrm{Ti}+\mathrm{NiTi}+\mathrm{Ag}(\mathrm{s}, \mathrm{s})+\mathrm{Cu}(\mathrm{s}, \mathrm{s}) / \mathrm{Invar}$.

\section{Conclusions}

Deposition of $\mathrm{CaCO}_{3}$ micrograins on QFSC was obtained by chemical reaction at room temperature; the micrograins improve the wettability of composites. The shearing strength of the brazed joint reached 11.6 MPa at room temperature, which is about five times the strength of joints of that obtained without surface filling.

Active braze reacted with QFSC fibers and formed a reaction layer about 5-8 $\mu \mathrm{m}$ thick. The structure of the brazed joint was: QFSC/3CaO $2 \mathrm{SiO}_{2}+\mathrm{Ti}_{3} \mathrm{O}_{5}+\mathrm{Fe}_{2} \mathrm{Ti}+\mathrm{NiTi}+\mathrm{Ag}(\mathrm{s}, \mathrm{s})+$ $\mathrm{Cu}(\mathrm{s}, \mathrm{s}) /$ Invar.
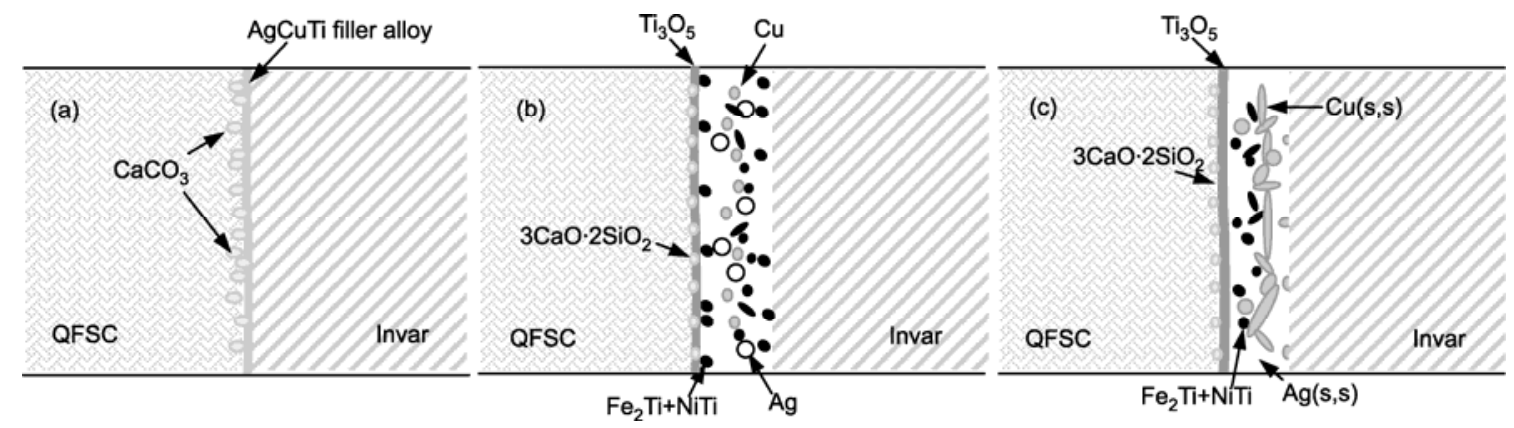

Figure 5 Model of micrograin-filled QFSC and Invar brazing using AgCuTi solder: (a) at room temperature, (b) solid solution reinforcement and interface reaction, and (c) cooling.

This work was supported by the National Natural Science Foundation of China (50705022) and the National Key Laboratory of Advanced Welding Production Technology of China.

1 Ayranci C, Carey J. 2D braided composites: A review for stiffness critical applications. Compos Struct, 2008, 85: 43-58

2 Gu B H, Chang F K. Energy absorption features of 3-D braided rectangular composite under different strain rates compressive loading. Aerosp Sci Technol, 2007, 11: 535-545

3 Wan Y Z, Zak G, Naumann S, et al. Study of 2.5-D glass-fabric-reinforced light-curable resin composites for orthotic applications. Compos Sci Technol, 2007, 67: 2739-2746

4 Isaac M D, Jyi J L, Patrick M S. Three-dimensional characterization of textile composites. Composites Part B, 2008, 39: 13-19

5 Henager Jr C H, Shin Y, Blum Y, et al. Coatings and joining for SiC and SiC-composites for nuclear energy systems. J Nucl Mater, 2007, 367-370: 1139-1143

6 Zhang G F, Zhang J X, Pei Y, et al. Joining of $\mathrm{Al}_{2} \mathrm{O}_{3} \mathrm{p} / \mathrm{Al}$ composites by transient liquid phase (TLP) bonding and a novel process of active-transient liquid phase (A-TLP) bonding. Mater Sci Eng A, 2008, 488: $146-156$

7 Singh M, Asthana R. Characterization of brazed joints of C-C composite to Cu-clad-Molybdenum. Compos Sci Technol, 2008, 68: 3010-3019

8 Xiong J T, Li J L, Zhang F S, et al. Direct joining of 2D carbon/carbon composites to Ti-6Al-4V alloy with a rectangular wave interface.
Mater Sci Eng A, 2008, 488: 205-213

9 Miura M, Shindo Y, Narita F, et al. Mode III fatigue delamination growth of glass fiber reinforced polymer woven laminates at cryogenic temperatures. Cryogenics, 2009, 49: 407-412

10 Hülsenberg D, Fehling P, Leutbecher T. Damage tolerant, translucent oxide fiber/glass matrix composites. Composites Part B, 2008, 39: 362-373

11 Hsengji H, Anthony M W. Compressive response of Z-pinned woven glass fiber textile composite laminates: Experiments. Compos Sci Technol, 2009, 69: 2331-2337

12 Alince B, Bednar F, van de Ven T G M. Deposition of calcium carbonate particles on fiber surfaces induced by cationic polyelectrolyte and bentonite. Colloids Surf A, 2001, 190: 71-80

13 Miao S. Polymer surface modification and characterization of particulate calcium carbonate fillers. Appl Surf Sci, 2003, 220: 359-366

14 Kliauga A M, Travessa D, Ferrante M. $\mathrm{Al}_{2} \mathrm{O}_{3} / \mathrm{Ti}$ interlayer/AISI 304 diffusion bonded joint: Microstructural characterization of the two interfaces. Mater Charact, 2001, 46: 65-74

15 Chen Z, Cao M S, Zhao Q Z, et al. Interfacial microstructure and strength of partial transient liquid-phase bonding of silicon nitride with Ti/Ni multi-interlayer. Mater Sci Eng A, 2004, 380: 394-401

16 Lu P W. Science Base of Inorganic Materials (in Chinese). Wuhan: Wuhan University of Technonogy Press, 1996

17 Dash S, Kamruddin M, Ajikumar P K, et al. Nanocrystalline and metastable phase formation in vacuum thermal decomposition of calcium carbonate. Thermochim Acta, 2000, 363: 129-135

Open Access This article is distributed under the terms of the Creative Commons Attribution License which permits any use, distribution, and reproduction in any medium, provided the original author(s) and source are credited. 